\title{
THE EFFECT OF BULB SIZE AND APPLICATION METHOD OF ASAHI SL BIOSTIMULATOR ON THE GROWTH AND YIELD OF Allium moly L.
}

\author{
Halina Laskowska, Elżbieta Pogroszewska, Wojciech Durlak, Danuta Kozak \\ Institute of Ornamental Plants and Architecture of Landscape, University of Life Sciences in Lublin \\ Leszczyńskiego 58, 20-068 Lublin, Poland \\ e-mail: epogroszewska@wp.pl
}

Received: 19.11.2012

\begin{abstract}
An experiment aimed at examining the effect of bulb size and the method of application of Asahi SL biostimulator on the growth and yield of Allium moly L. was conducted in the years 2005-2008. Four sizes of bulbs were used in the experiment (3-4, 4-5, 5-6, and 6-7 cm in circumference). Asahi SL was applied in the following combinations: bulb soaking for 45 minutes in the biostimulator solution prior to planting; plant spraying at the green bud stage; soaking combined with plant spraying; and the control treatment without application of the stimulator. Asahi SL was applied at a concentration of $0.2 \%$. After the first frost, the experimental plots were mulched with wheat straw. During the experiment, the decorative value of the plants was evaluated and the following features were determined: inflorescence stem length, inflorescence diameter, and number of flowers per inflorescence. Total yield was evaluated after bulb harvest. The size of Allium moly bulbs planted was found to determine the quality of inflorescence stems and total yield of daughter bulbs expressed in their number and weight. Inflorescence stems of high ornamental value and high total yield of daughter bulbs resulted from planting bulbs of 5-6 and 6-7 cm in circumference. The application of $0.2 \%$ solution of Asahi by spraying green buds or the combination of spraying and bulb soaking prior to planting are very beneficial for the quality of inflorescence stems and yield of daughter bulbs. The application of $0.2 \%$ solution of Asahi SL by plant spraying leads to an increase in total quantitative yield of bulbs by $10 \%$ or $8 \%$ in case of the combined use of both application methods. Bulb soaking combined with plant spraying leads to an increase in total weight of bulbs by $41 \%$.
\end{abstract}

Key words: ornamental garlic, plant spraying, bulb soaking, morphological features

\section{INTRODUCTION}

Ornamental garlic belongs to an interesting group of ornamental plants and it becomes more and more popular on the flower market. Hence, there have been attempts to improve methods of its cultivation. Apart from the size of planted bulbs ( $\mathrm{He} t \mathrm{~m}$ a $\mathrm{n}$ et al. 2007), growth and yield of bulbous plants can be affected by application of all kinds of growth regulators that enhance plant development processes and improve their quality. Among such substances, there are retardants, which have already been used for a long time in ornamental plant cultivation (P o b u d ki e w i c z, 2008), and biostimulators. One of them is Asahi SL. Its components stimulate the synthesis of several compounds (hormones) in plants, leading to enhancement of plant activity, better acquisition of nutrients, etc. The application of growth regulators is extremely important in situations stressful to plants and in unfavorable weather conditions. They can support cultivation when there is a risk of obtaining lower yield than planned or plant material of lower quality (www.asahi.pl). The application of Asahi SL, in various forms, has a positive influence on the quality traits of plants such as Vitis vinifera L., Arabidopsis thaliana L. and Amaranthus paniculatus L. (Górnik et al. 2007; Przybysz et al. 2010; Gaw rońska and Przy bysz, 2011). The study conducted by Laskowska and Kocira (2002) as well as by Marcinek and Het man (2005) showed a positive effect of Asahi SL on the morphological traits of plants as well as on the number of daughter corms in total yield of Acidanthera bico$l o r$, and on weight and number of corms produced in axils of leaves of Sparaxis tricolor. It is beneficial to apply this biostimulator in two forms: bulb soaking prior to planting and plant spraying during the growing season.

The aim of this experiment was to examine the effect of bulb size and the method of Asahi SL 
biostimulator application on the morphological traits of plants and on yield of Allium moly L. bulbs.

\section{MATERIALS AND METHODS}

The experiment was conducted between the years 2005-2008. Allium moly L. was planted every year $(2005,2006,2007)$ in the 3rd decade of September $\left(23^{\text {rd }}-25^{\text {th }}\right.$, Sept.). Bulbs used in the experiment had a circumference of 3-4, 4-5, 5-6, 6-7 cm. Three methods of Asahi SL application were used: bulb soaking in $0.2 \%$ solution of the biostimulator prior to planting, spraying with the solution at the sessile green bud stage, bulb soaking combined with plant spraying. Plants treated with distilled water were used as the control. Bulbs were soaked in $0.2 \%$ Asahi SL solution for 45 minutes and planted in $1 \mathrm{~m}^{2}$ plots, 45 pieces per plot. Prior to planting, they were disinfected in $1 \%$ Kaptan solution and $0.7 \%$ Topsin solution. Bulbs treated earlier with Asahi SL were soaked in this preparation after 24 hours. The plots were mulched with wheat straw after the first frost. During the growing period, plant phenological phases were observed: beginning of flowering (25\% of blooming plants per plot), full flowering (75\% of blooming plants on the plot), and its end. During the full flowering stage, several measurements were taken: inflorescence stem length, inflorescence diameter, and number of flowers per inflorescence. After harvest bulbs were dried and cleaned.
Then, the yield was evaluated in terms of number and weight of bulbs. The experiment was set up in a randomized block design in 5 replications. One plot was one replication. The results were statistically analysed by analysis of variance. Significant differences were determined with Tukey's test at $=0.05$.

\section{RESULTS}

Allium moly L., depending on the year of the study, bloomed between the $8^{\text {th }}$ and $12^{\text {th }}$ of June. Plants that grew from bulbs of 6-7 cm in circumference bloomed earliest (June $8^{\text {th }}$ ). Full flowering was observed at the end of the second decade of June. The highest number of flowering plants was obtained from bulbs of 6-7 cm in circumference $(92.4 \%)$ and they bloomed longest ( $2.5-3$ weeks). The smallest number of flowering plants was obtained from bulbs of $3-4 \mathrm{~cm}$ in circumference $(17.7 \%)$ and they flowered shortest (1.5 week). Alliums sprayed with $0.2 \%$ solution of Asahi SL bloomed longer in comparison to those treated with water (18-20 days on average).

The analysis of the decorative value of Allium moly L. showed that it depended on the size of bulbs planted. Plants that grew from bulbs of $6-7 \mathrm{~cm}$ in circumference were characterized by the longest inflorescence stems, the largest inflorescence diameter, and the highest number of flowers per inflorescence (Table 1).

Table 1

Effect of size of planted bulbs and Asahi SL application method on morphological traits of Allium moly L. Means for 3 years

\begin{tabular}{|c|c|c|c|c|c|c|c|}
\hline $\begin{array}{l}\text { Bulb } \\
\text { circumference } \\
\text { in cm }\end{array}$ & $\begin{array}{l}\text { Application } \\
\text { method }\end{array}$ & $\begin{array}{l}\text { Inflorescence } \\
\text { stem length in } \\
\mathrm{cm}\end{array}$ & $\begin{array}{c}\text { Mean } \\
\text { for bulb } \\
\text { circumference }\end{array}$ & $\begin{array}{l}\text { Inflorescence } \\
\text { diameter } \\
\text { in cm }\end{array}$ & $\begin{array}{c}\text { Mean } \\
\text { for bulb } \\
\text { circumference }\end{array}$ & $\begin{array}{l}\text { Number of } \\
\text { flowers per } \\
\text { inflorescence } \\
\text { in pcs }\end{array}$ & $\begin{array}{c}\text { Mean } \\
\text { for bulb } \\
\text { circumference }\end{array}$ \\
\hline \multirow{4}{*}{$3-4$} & Control & $24.7 a^{*}$ & \multirow{4}{*}{$25.2 \mathrm{~A}$} & $5.9 \mathrm{a}$ & \multirow{4}{*}{$6.1 \mathrm{~A}$} & $12.7 \mathrm{ab}$ & \multirow{4}{*}{$12.8 \mathrm{~A}$} \\
\hline & Bulb soaking & $24.5 \mathrm{a}$ & & $6.1 \mathrm{a}$ & & $12.2 \mathrm{a}$ & \\
\hline & Plant spraying & $26.0 \mathrm{~b}$ & & $6.1 \mathrm{a}$ & & $12.9 \mathrm{ab}$ & \\
\hline & Soaking + spraying & $25.7 \mathrm{~b}$ & & $6.2 \mathrm{a}$ & & $13.6 \mathrm{~b}$ & \\
\hline \multirow{4}{*}{$4-5$} & Control & $27.8 \mathrm{c}$ & \multirow{4}{*}{$28.6 \mathrm{~B}$} & $6.7 \mathrm{~b}$ & \multirow{4}{*}{$7.0 \mathrm{~B}$} & $16.9 \mathrm{c}$ & \multirow{4}{*}{$18.2 \mathrm{~B}$} \\
\hline & Bulb soaking & $28.2 \mathrm{c}$ & & $6.9 \mathrm{bc}$ & & $16.4 \mathrm{c}$ & \\
\hline & Plant spraying & $29.1 \mathrm{~d}$ & & $7.2 \mathrm{~cd}$ & & $18.2 \mathrm{de}$ & \\
\hline & Soaking + spraying & $29.4 \mathrm{~d}$ & & $7.4 \mathrm{de}$ & & $17.2 \mathrm{~cd}$ & \\
\hline \multirow{4}{*}{$5-6$} & Control & $32.0 \mathrm{fe}$ & \multirow{4}{*}{$31.1 \mathrm{C}$} & $7.5 \mathrm{def}$ & \multirow{4}{*}{$7.6 \mathrm{C}$} & $19.1 \mathrm{e}$ & \multirow{4}{*}{$20.6 \mathrm{C}$} \\
\hline & Bulb soaking & $31.2 \mathrm{e}$ & & $7.6 \mathrm{efg}$ & & $20.5 \mathrm{f}$ & \\
\hline & Plant spraying & $31.4 \mathrm{e}$ & & $7.7 \mathrm{e}-\mathrm{h}$ & & $21.6 \mathrm{~g}$ & \\
\hline & Soaking + spraying & $31.5 \mathrm{e}$ & & $7.5 \mathrm{def}$ & & $21.0 \mathrm{f}$ & \\
\hline \multirow{4}{*}{$6-7$} & Control & $33.1 \mathrm{~g}$ & \multirow{4}{*}{$33.0 \mathrm{D}$} & $7.8 \mathrm{fgh}$ & \multirow{4}{*}{$8.0 \mathrm{D}$} & $23.3 \mathrm{hi}$ & \multirow{4}{*}{$23.7 \mathrm{D}$} \\
\hline & Bulb soaking & $32.5 \mathrm{gf}$ & & $7.9 \mathrm{gh}$ & & $24.2 \mathrm{~h}$ & \\
\hline & Plant spraying & $33.1 \mathrm{~g}$ & & $8.0 \mathrm{~h}$ & & $23.1 \mathrm{~h}$ & \\
\hline & Soaking + spraying & $33.2 \mathrm{~g}$ & & $8.0 \mathrm{~h}$ & & $24.2 \mathrm{~h}$ & \\
\hline \multirow{4}{*}{$\begin{array}{l}\text { Mean for } \\
\text { application } \\
\text { method }\end{array}$} & Control & $28.9 \mathrm{~A}$ & & $7.0 \mathrm{~A}$ & & $18.0 \mathrm{~A}$ & \\
\hline & Bulb soaking & $29.1 \mathrm{AB}$ & & $7.1 \mathrm{AB}$ & & $18.3 \mathrm{AB}$ & \\
\hline & Plant spraying & $29.9 \mathrm{~B}$ & & $7.3 \mathrm{~B}$ & & $18.9 \mathrm{~B}$ & \\
\hline & Soaking + Spraying & $29.9 \mathrm{~B}$ & & $7.3 \mathrm{~B}$ & & $19.1 \mathrm{~B}$ & \\
\hline
\end{tabular}

*Means followed by the same letter are not significantly different at $=0.05$ level of probability. 
The analysis of Allium moly L. yield showed that the size of planted bulbs significantly differentiated the number and weight of total bulb yield (Table 2 ). The highest number and weight of bulbs in total yield was obtained by planting bulbs of $6-7 \mathrm{~cm}$ in

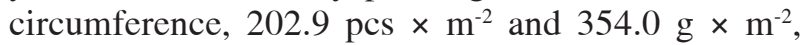
respectively.

Asahi SL used in this experiment in the form of plant spraying or by combining two application methods, bulb soaking and plant spraying, had a positive effect on the quality traits of Allium moly L. plants (Table 1). After application of Asahi SL, inflorescence stem length and inflorescence diameter increased in comparison to the control. What is more, a greater number of flowers per inflorescence was observed.
The number of bulbs in total yield was significantly higher in comparison to the control when plants were sprayed with $0.2 \%$ solution of Asahi SL during the growing season, at the green bud stage $\left(152 \mathrm{pcs} \times \mathrm{m}^{-2}\right)$, or the two application methods were used in combination (bulb soaking prior to planting + plant spraying, $\left.148.5 \mathrm{pcs} \times \mathrm{m}^{-2}\right)($ Table 2). Weight of bulbs in total yield was significantly higher after application of both forms of Asahi application together $\left(323.9 \mathrm{~g} \times \mathrm{m}^{-2}\right)$. After application of Asahi SL in the form of plant spraying, a $10 \%$ increase in yield in terms of numbers and a $12.4 \%$ increase in yield in terms of weight were found. By combining bulb soaking prior to planting with plant spraying, an increase in the total number of bulbs by $7 \%$ was observed. Such method of application increased weight yield by $41 \%$ in comparison to the control combination.

Table 2.

Effect of size of planted bulbs and Asahi SL application method on total bulb yield of Allium moly L. Means for 3 years

\begin{tabular}{|c|c|c|c|c|c|}
\hline $\begin{array}{l}\text { Bulb } \\
\text { circumference } \\
\text { in } \mathrm{cm}\end{array}$ & $\begin{array}{l}\text { Application } \\
\text { method }\end{array}$ & $\begin{array}{c}\text { Total } \\
\text { bulb yield } \\
\left(\mathrm{pcs} \times \mathrm{m}^{-2}\right)\end{array}$ & $\begin{array}{l}\text { Mean for bulb } \\
\text { circumference }\end{array}$ & $\begin{array}{c}\begin{array}{c}\text { Total } \\
\text { bulb yield } \\
\left(\mathrm{g} \times \mathrm{m}^{-2}\right)\end{array} \\
\end{array}$ & $\begin{array}{l}\text { Mean for bulb } \\
\text { circumference }\end{array}$ \\
\hline \multirow{4}{*}{$3-4$} & Control & $79.3 \mathrm{a}$ & \multirow{4}{*}{$81.4 \mathrm{~A}$} & $109.9 \mathrm{ab}$ & \multirow{4}{*}{$113.1 \mathrm{~A}$} \\
\hline & Bulb soaking & $69.7 a^{*}$ & & $91.6 \mathrm{a}$ & \\
\hline & Plant spraying & $90.8 \mathrm{ab}$ & & $129.1 \mathrm{abc}$ & \\
\hline & Soaking + spraying & $85.9 \mathrm{ab}$ & & $122.1 \mathrm{ab}$ & \\
\hline \multirow{4}{*}{$4-5$} & Control & $118.0 \mathrm{bc}$ & \multirow{4}{*}{$126.8 \mathrm{~B}$} & $188.7 \mathrm{~b}-\mathrm{e}$ & \multirow{4}{*}{200.7 B } \\
\hline & Bulb soaking & $115.0 \mathrm{bc}$ & & $177.6 \mathrm{a}-\mathrm{d}$ & \\
\hline & Plant spraying & $136.3 \mathrm{~cd}$ & & $219.3 c-f$ & \\
\hline & Soaking + spraying & 137.9 cde & & $217.3 \mathrm{c}-\mathrm{f}$ & \\
\hline \multirow{4}{*}{$5-6$} & Control & $145.3 \mathrm{ef}$ & \multirow{4}{*}{$165.3 \mathrm{C}$} & $256.4 \mathrm{~d}-\mathrm{g}$ & \multirow{4}{*}{$283.6 \mathrm{C}$} \\
\hline & Bulb soaking & 170.2 ef & & $280.3 \mathrm{e}-\mathrm{h}$ & \\
\hline & Plant spraying & $177.6 \mathrm{f}$ & & $314.3 \mathrm{gh}$ & \\
\hline & Soaking + spraying & $168.1 \mathrm{def}$ & & $283.6 \mathrm{fgh}$ & \\
\hline \multirow{4}{*}{$6-7$} & Control & $209.5 \mathrm{f}$ & \multirow{4}{*}{$202.9 \mathrm{D}$} & $364.0 \mathrm{~h}$ & \multirow{4}{*}{$354.0 \mathrm{D}$} \\
\hline & Bulb soaking & $196.3 \mathrm{f}$ & & $332.9 \mathrm{gh}$ & \\
\hline & Plant spraying & $203.6 \mathrm{f}$ & & $370.4 \mathrm{~h}$ & \\
\hline & Soaking + Spraying & $202.3 \mathrm{f}$ & & $348.7 \mathrm{gh}$ & \\
\hline \multirow{4}{*}{$\begin{array}{l}\text { Mean } \\
\text { for application } \\
\text { method }\end{array}$} & Control & $138.0 \mathrm{~A}$ & & $229.7 \mathrm{~A}$ & \\
\hline & Bulb soaking & $137.8 \mathrm{~A}$ & & $220.6 \mathrm{~A}$ & \\
\hline & Plant spraying & $152.0 \mathrm{~B}$ & & $258.2 \mathrm{~B}$ & \\
\hline & Soaking + Spraying & $148.5 \mathrm{~B}$ & & $323.9 \mathrm{C}$ & \\
\hline
\end{tabular}

*Means followed by the same letter are not significantly different at $=0.05$ level of probability.

\section{DISCUSSION}

A significant problem in ornamental plant production is the possibility to increase the quantity and quality of yield. For ornamental plants, it relates to yield of flowers and yield of daughter bulbs. Cultivation methods are constantly improved with respect to the simplest agrotechnical methods and the use of growth regulators.

The results of this research confirm that planting larger bulbs results in better quality of produced plants and in higher total yield expressed in number and weight of bulbs.

$\mathrm{H}$ a y d a r et al. (2007) proved that planting bulbs of larger diameter in the cultivation of Allium cepa $\mathrm{L}$. had a positive effect on the height of plants, fresh weight of bulbs, and their length. Similar results were obtained by M o s le h Ud - D e e n (2008) and A s h r a f u z z a m a n et al. (2009) in the cultivation of Allium сера L. Planting large maternal bulbs increased yield of bulbs in terms of weight and number as well as yield of seeds. In the cultivation of Polianthes tuberosa L. 
cv. Single, A hmad et al. (2009) used larger bulbs, which enhanced growth dynamics, improved quality of flowers and increased yield of daughter bulbs. Addai and Scott (2011) in their research on the cultivation of hyacinths and lilies noted that when large bulbs were planted they obtained flowers of better quality and higher yield of daughter bulbs than when smaller bulbs were planted.

The biostimulator Asahi SL had a positive effect of the quality of Allium moly plants, which expressed itself in a longer inflorescence stem and diameter as well as a higher number of flowers per inflorescence. Similar results were obtained by $\mathrm{A} \mathrm{d} \mathrm{a} \mathrm{mi} \mathrm{a} \mathrm{k} \mathrm{and}$ He t $\mathrm{m}$ a n (2006) in the production of 'Flamingo' roses where Asahi SL stimulated the formation of stems and improved significantly the quality of produced plants by increasing the weight of shrubs and the root crown diameter. Spraying annual shrubs of Rosa multiflora Thunb. with the Asahi SL biostimulator had a positive effect on the quality parameters of rootstock (Hetman and Adamiak, 2003). In the cultivation of Arabidopsis thaliana L., the application of this biostimulator by spraying leaves increased fresh and dry weight of the following aboveground parts: inflorescence and leaf rosette (P r z y b y s z et al. 2010). In tulip cultivation, it had a positive effect on the postharvest quality of inflorescence stems ( $\mathrm{S} \mathrm{z} \mathrm{ot}$ and $\mathrm{Het}$ $\mathrm{m}$ a $\mathrm{n}, 2003)$. The obtained results are concurrent with those obtained by $\mathrm{Krajew}$ ska and Latkow ska (2008) who achieved a significant improvement in height and quality of Bergenia cordifolia and Hosta plants after application of Asahi SL in the form of spraying. A positive effect of Asahi SL has also been found in the cultivation of other plants: corn ( $\mathrm{Michalski}$ et al. 2008a), sugar beet (K o s i t orn a and S molin s k i ,2008), and maize (K s i ę ż a k, 2008; M i c h a ls ki et al. 2008b).

Asahi SL was found to have a positive effect on yield of daughter bulbs of Allium moly in the present experiment. A similarly advantageous effect of this biostimulator on yield of potato tubers was observed by M a c i e j e w s ki et al. (2008). However, the environmental conditions during the growing season may influence the efficiency of Asahi SL activity (M a t y s i a k et al. 2011).

\section{CONCLUSIONS}

1. The size of Allium moly bulbs planted determines the quality of inflorescence stems and total yield of daughter bulbs in terms of number and weight.

2. Inflorescence stems of high ornamental value and high total yield of daughter bulbs are obtained by planting bulbs of 5-6 and 6-7 $\mathrm{cm}$ in circumference.

3. The application of $0.2 \%$ solution of Asahi by spraying green buds or the combination of spraying and bulb soaking prior to planting are very beneficial for the quality of inflorescence stems and yield of daughter bulbs.

4. The application of $0.2 \%$ solution of Asahi SL by plant spraying increases total quantitative yield of bulbs by $10 \%$ or $8 \%$ in case of the combined use of both application methods. Bulb soaking combined with plant spraying increases total weight of bulbs by $41 \%$.

\section{Acknowledgements}

The studies were financed by the Ministry of Science and Informatization, project No 2 PO6R 01027

\section{REFERENCES}

Adamiak J., Hetman J. 2006. Wpływ Asahi na jakość jednorocznych krzewów róż odm. 'Flamingo'. / The influence of Asahi SL on the quality of one year old cultivar 'Flamingo' shrubs. Zesz. Probl. Post. Nauk Rol. 510: 19-24. (in Polish)

Addai I. K., Scott P. 2011. Influence of bulbs sizes at planting on the growth and development of the common hyacinth and the lily. Agric. Biol. J. N. Am. 2(2): 298314. http://dx.doi.org/10.5251/abjna.2011.2.2.298.314

Ahmad I., Ahmad T., Asif M., Saleem M., A kram A. 2009. Effect of bulb size on growth, flowering and bulbils production of tuberose. Sarhad J. Agric. 25(3): 391-398.

Ashrafuzzaman M., Millat M.N., Razi Ismail M., Shahidullah S.M. 2009. Influence of paclobutrazol and bulb sizes on seed yield and yield attributing traits of onion (Allium cepa L.) cv. Taherpuri. Arch. Agron. Soil Sci. 55(6): 609-621.

Gawrońska H., Przybysz A. 2011. Biostymulatory: mechanizmy działania i przykłady zastosowań. Mat. Konf. Targi Sadownictwa i Warzywnictwa. Warszawa 5-6. 01. 2011: 7-13. (in Polish)

Górnik K., Grzesik M., Mika A.2007. Improvement of grapevines rooting and growth of plants under stress conditions by Asahi SL. Folia Hortic. 19/2: 57-67.

Haydar A., Sharker N, Ahmed M.B., Hannan M.M., Razvy M.A., Hossain M., Hoque A. Karim R. 2007. Genetic variability and interrelationship in onion (Allium cepa $\mathrm{L}$.). Middle-East J. Sci. Res. 2(3-4): 132-134.

Hetman J., Adamiak J. 2003. Wpływ Asahi SL na jakość podkładki róży wielokwiatowej (Rosa multiflora Thunb.). / The influence of Asahi SL on the quality of rootstock of Rosa multiflora Thunb. Zesz. Probl. Post. Nauk Rol. 491: 61-67. (in Polish)

Hetman J., Laskowska H., Durlak W. 2007. The influence selected factors on the yield of Allium moly L. bulbs. Acta Sci. Pol., Hortorum Cultus, 6(2): 23-27. (in Polish) 
Kositorna J., Smoliński M. 2008. Asahi SL biostimulator in protection of sugar beet from herbicide stress. In: Biostimulators in Modern Agriculture. Field Crops. Editorial House Wieś Jutra, Warszawa: 41-49.

Krajewska J., Latkowska M. 2008. The effects of biostimulators Asahi SL and Siapton 10L on the growth of Bergenia cordifolia (Haw.) Sternb. 'Rotblum' and Hosta (Tratt.) 'Sum and Substance' and 'Minuteman'. In: Biostimulators in Modern Agriculture. Ornamental and special plants. Editorial House Wieś Jutra, Warszawa: 33-39.

Księżak J. 2008. Effect of biostimulator Asahi SL on yield of maize grain. In: Biostimulators in Modern Agriculture. Field Crops. Editorial House Wieś Jutra, Warszawa: $60-65$.

Laskowska H., Kocira A. 2002. Wpływ preparatu Asahi SL i nawozu Tytanit na cechy morfologiczne acidantery dwubarwnej (Acidanthera bicolor Hochst.). / Influence of Asahi SL and Tytanit growth stimulators on the morphological features of Acidanthera bicolor Hochst. Zesz. Probl. Post. Nauk Rol. 483: 141-147. (in Polish)

Maciejewski T., Michalski T., Bartos-Spychała M., Cieślicki W. 2008. Effect of the application of biostimulator Asahi SL on the yield of potato tubers and their quality. In: Bio-stimulators in Modern Agriculture. Solanaceous Crops. Editorial House Wieś Jutra, Warsaw: 52-60.

Maciejewski T., Szukała J., Jarosz A. 2007. Influence of biostimulator Asahi SL and Atonik SL on qualitative tubers of potatoes. J. Res. Appl. Agric. Eng. 52(3): 109-112.

Marcinek B., Hetman J. 2005. Wpływ Asahi SL na plonowanie sparaksisu trójbarwnego Sparaxis tricolor Ker-Gawl. Ogólnopolska Konferencja „Postęp w produkcji roślin ozdobnych" Skierniewice 31 styczeń-1 luty: 171-172. (in Polish)

Matysiak K., Adamczewski K., Kaczmarek S. 2011. Response of some crops cultivated in Great Poland to application of Asahi SL. Prog. Plant Protection/ Post. Ochr. Roślin, 51(4): 1849-1857.

Michalski T., Bartos-Spychała M., Maciejewski T., Jarosz A. 2008a. Effect of biostimulator Asahi SL on cropping of maize grown for grain. In: Biostimulators in modern agriculture. Field Crops. Wieś Jutra, Warszawa: 66-76.

Michalski T., Horoszkiewicz-Janka J., BartosSpychała M. 2008b. Efficiency of Asahi SL in protection of barley and wheat mixture in comparison with pure sowing. In: Biostimulators in Modern Agriculture. Field crops. Wieś Jutra, Warszawa: 50-59.

Mosleh Ud-Deen MD., 2008. Effect of mother bulb size and planting time on growth, bulb and seed yield of onion. Bangladesh J. Agric. Res. 33(3): 531-537.
Pobudkiewicz A. 2008. The influence of growth retardants and cytokinins on flowering of ornamental plants. Acta Agrobot. 61(1): 137-141.

Przybysz A., Wrochna M., Słowiński A., Gawrońska H. 2010. Stimulatory effect of Asahi SL on selected plant species. Acta Sci. Pol. Hort. Cultus, 9(2): 53-64.

Szot P., Hetman J. 2003. Ocena wpływu stymulatorów wzrostu na zmienność właściwości mechanicznych łodyg tulipana. / Evaluation of the effect of growth regulators on the variation in mechanical properties of tulip stems. Folia Hortic. Suplement 2: 10-12. (in Polish)

\section{Wpływ wielkości cebul \\ i sposobu aplikacji biostymulatora Asahi SL na wzrost i plonowanie czosnku złocistego (Allium moly L.)}

\section{Streszczenie}

Celem badań, które prowadzono w latach 2005-2008, było określenie wpływu wielkości cebul i sposobu aplikacji biostymulatora Asahi SL na wzrost i plonowanie czosnku złocistego (Allium moly L.). Wykorzystano cebule o obwodzie: 3-4, 4-5, 5-6 i 6-7 cm. Zastosowano następujące traktowania: moczenie cebul przez 45 minut przed sadzeniem w roztworze biostymulatora, opryskiwanie roślin w fazie zielonego pąka, moczenie połączone $\mathrm{z}$ opryskiwaniem roślin i kombinacja kontrolna bez stosowania stymulatora. Asahi SL aplikowano w stężeniu 0,2\%. Po pierwszych przymrozkach poletka doświadczalne ściółkowano słomą pszenną. Oceniono walory dekoracyjne roślin takie jak: długość pędu kwiatostanowego, średnica kwiatostanu i liczba kwiatów w kwiatostanie. Po zbiorze cebul oceniono plon ogólny. Wielkość sadzonych cebul A. moly decyduje o jakości pędów kwiatostanowych i plonie ogólnym cebul potomnych wyrażonym jego liczbą i masą. Pędy kwiatostanowe o dużych walorach zdobniczych i wysoki plon ogólny cebul potomnych zapewnia sadzenie cebul o obwodzie 5-6 i 6-7 cm. Korzystne jest stosowanie 0,2\% roztworu Asahi SL w formie opryskiwania roślin na zielony pąk, bądź łączenia opryskiwania z moczeniem cebul przed sadzeniem, ze względu na jakość pędów kwiatostanowych i plon cebul potomnych. Stosowanie $0,2 \%$ roztworu Asahi SL w formie opryskiwania roślin, skutkuje wzrostem ogólnego plonu liczbowego cebul o $10 \%$, a łączne stosowanie obu form aplikacji o około $8 \%$. Moczenie cebul połączone z opryskiwaniem roślin powoduje wzrost ogólnej masy cebul o $41 \%$. 
